\title{
Determinants of Wheat Production in Libya
}

\section{Fouzi Salih Faraj, Farhana Ismail \& Rossazana Ab-Rahim}

To Link this Article: http://dx.doi.org/10.6007/IJARBSS/v10-i12/8284

DOI:10.6007/IJARBSS/v10-i12/8284

Received: 10 October 2020, Revised: 12 November 2020, Accepted: 28 November 2020

Published Online: 15 December 2020

In-Text Citation: (Faraj et al., 2020)

To Cite this Article: Faraj, F. S., Ismail, F., \& Ab-Rahim, R. (2020). Determinants of Wheat Production in Libya. International Journal of Academic Research in Business and Social Sciences, 10(12), 178-191.

\section{Copyright: (c) 2020 The Author(s)}

Published by Human Resource Management Academic Research Society (www.hrmars.com)

This article is published under the Creative Commons Attribution (CC BY 4.0) license. Anyone may reproduce, distribute, translate and create derivative works of this article (for both commercial and non-commercial purposes), subject to full attribution to the original publication and authors. The full terms of this license may be seen

at: http://creativecommons.org/licences/by/4.0/legalcode

\section{Vol. 10, No. 12, 2020, Pg. 178 - 191}

Full Terms \& Conditions of access and use can be found at http://hrmars.com/index.php/pages/detail/publication-ethics 


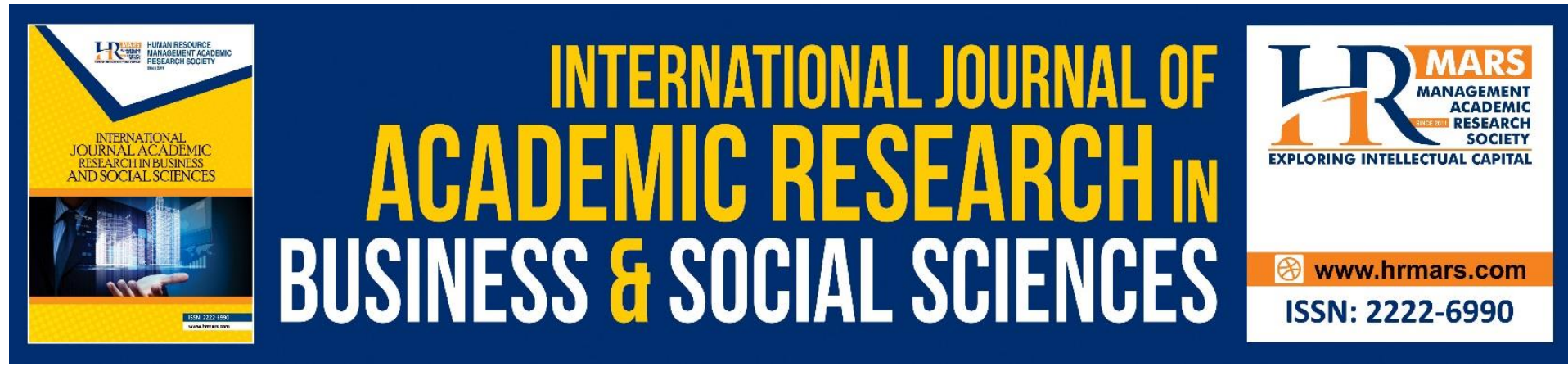

\title{
Determinants of Wheat Production in Libya
}

\author{
Fouzi Salih Faraj, Farhana Ismail \& Rossazana Ab-Rahim \\ Benghazi University, Benghazi, Libya Universiti Malaysia Sarawak, Sarawak, Malaysia
}

\begin{abstract}
Agriculture has an important place in Libyan economy since it is a major source and necessary to maintain this sector to ensure food and food security. The purpose of this study is to examine the effect of the cultivated of wheat, rainfall and temperature range on wheat production. Time-series data were employed and analysed by using the ARDL bounds test approach of cointegration. The results of estimated coefficients in long run relationship indicate that cultivated of wheat has a positive effect on wheat production and highly significant influence at $1 \%$ probability level. Likewise, rainfall is found to be a positive sign related to wheat production but not significant. Meanwhile, the effect of temperature is negatively associated with wheat and non-significant at probability levels.
\end{abstract}

Keywords: Cultivated Area, Rainfall, Temperature, Wheat Production, Libya

\section{Introduction}

The agricultural sector one of the most sectors seeks to achieve economic prosperity through its strategic role in the country's economic development process (Praburaj, 2018). Specifically, the agricultural sector contributes providing employment opportunities; source in foreign trade which is needed for capital and maintenance imports required in the non-agricultural sector (Bijaya, 2010) as well as it is a key component of the industrial economy. Consequently, plays an important role in food supplies to the local market and producer goods for export (Nurgaziev, 2010).

Wheat is arguably the most important food crop in the world. (Morris and Rose, 1996) and has played an outstanding role in feeding a hungry world and improving global food security (Shiferaw et al., 2013). In addition to provides substantial amounts of several components that are essential or beneficial for health, notably protein, vitamins (notably B vitamins), dietary fibre, and phytochemicals (Shewry and Hey, 2015; Darwish et al, 2018).

The wheat crop in Libya is one of the important grains exclusively in the composition of some local food industries and using its secondary output for animal feed (Abdel Aty, 2018). Therefore, the wheat cultivation in Libya has received a great deal of attention, due to its importance in providing this crop for the people and reduce the import of this commodity (Ministry of Information and Culture, 1994).

In this context, Libya has adopted many different plans and comprehensive agricultural policies (Al-Maslati, 2012). These plans and policies were implemented to further develop and 
modernize agricultural projects to increasing the amount of wheat product, as well as providing irrigation resources for these projects by establishing Industrial River (Ministry of Information and Culture, 1994). Based on this interest of the Libyan state in this strategic crop, production increased from 140,500 tons in 1980 to in 209,737 tons 1983 and then reduces to 124,000 tons in 1996; increased again in 1997 to 156,400 tons. At the same time, the value of total wheat production declined from 140,000 tons in the year 1998 to 132,239 tons in 2010 and increased again in 2014 to 200,000 tons (FAOSTAT, 2020).

The security of food is a major issue in today's world. United nation and other international organizations are very pessimistic about the current food situation in the world (Chandio et al., 2020). Therefore, Libya seeks to secure self-sufficiency of the wheat crop due to this sector has an apparent deficit in local production as result of increased quantities of it consumed for different purposes, as it is clear from the data that related to import statistics records in 2013 the wheat import value was (420.71) Million U.S. Dollars (Arab Organization for Agricultural Development, 2016). Thus, this study attempting to examine the effect of the cultivated of wheat, rainfall and temperature range on wheat production in Libya during the period 19802014 by using the ARDL approach and providing empirical information to make the result more meaningful to improve the wheat production and regain this sector its activity in deficit coverage.

\section{Literature Review}

Agricultural policies in Libya and the strategy for achieving food security seek to know the effectiveness of agricultural economic policies in achieving food security and maintaining the current level of nutrition for the individual in Libya by studying the development of applied policies that aim to achieve the greatest possible degree of food self-sufficiency In this context, the reference review includes previous studies in the field of wheat production in Libya, as it includes a summary of the most important information conducted in this field to identify on the most important results obtained.

\section{Cultivated Area}

Land is to be considered the most important aspect of production, especially agricultural production. The earliest studies representative of estimates for farm firm was published by Kamiya of Tokyo University in 1941 and proved that there is a positive association between agricultural area coefficient and production in paddy firms (Heady and Dillon, 2006). In the same vein, the Food and Policy Research Institute (FAPRI) estimates that an additional 6 million ha of corn and 4 million ha of wheat plus a roughly $12 \%$ increase in global corn and wheat yields will be used to produce this additional 200 million tonne of grain. Both increases in planted area and increases in yield are likely to be needed to meet global demand for grain (Edgerton, 2009).

In the context of Libya, Al-Daeheh in 2005 on some of the determinants of wheat production in Libya, where the study targeted some specific factors for wheat production and the study relied on the simple and multiple regression methods. The study indicated that there was an increase in the area cultivated for the wheat crop during the eighties due to the state's encouragement of the agricultural sector. Based on statistical results analysis the study concluded that the restricted area is one of the most important factors affecting the volume of wheat production. In another stream of past studies supported the proposition that large, 
cultivated wheat effect on increase wheat production that connected by Al- Dabah (1991) on economics study of rain-fed wheat supply in Libya during the period of 1960 to 1988.

In addition, Shalgam (1995) conducted a study on wheat productivity in desert projects at the cultivated area level. The study showed that wheat production varied from one project to another due to the area. Also, the positive nexus is further confirmed by Bashir (1996) in his economic study of the production of grains and wheat, the study recommended that the large area that was reclaimed to achieve self-sufficiency and that the cultivated area was one of the most important influences on production and comes first in that an introduction to the area. And the grain crops emphasized their great importance from the economic, food, and industrial aspects in Libya, and came first in terms of area, which is estimated at about $75 \%$ of the cultivated area.

Khayriyah (2005) identified the food security situation in Libya by identifying the development of both the consumption of energy and the production capacity of the commodities and the main food groups and the identification of the food level. The study relied on time series data, and the study showed that the consumption energy in Libya, has taken an increasing trend in general, including grains, wheat, rice, barley, maize, sugar, potatoes, oils, and fats, as it was found that the cultivated area of wheat, barley, maize, and potatoes has taken a decreasing trend in general.

In the study of Gade (2006) that estimating the response function of wheat supply in Libya, the study aimed to identify the current state of wheat cultivation by deriving the equation of the general temporal trend of the most important economic variables for wheat production in Libya in addition to identifying the most important of these variables by estimating the response function for crop production. The finding of the study demonstrated that there was an increase in the area cultivated for the wheat crop during the eighties due to the state's encouragement of the agricultural sector and it is one of the most important factors affecting the volume of wheat production. In harmony with this, Zawam (2007) examined in an economic study affecting the production and consumption of the most important grain crop in Libya, and the study aimed to identify the problem of production and consumption of the most important cereal crops (wheat and barley) and study the determining factors for their production. The study results revealed that the most important determinants of wheat production in Libyan agriculture were the area.

Al-Bashir and Mahmoud (2008) aimed to determine the optimal production volume for the most important major crops in Libya during the period (1990-1997). The study showed that the cultivable area is about 3.8 million hectares of the country's area, and the cultivated area is about 2.28 million hectares until 2007 , i.e., $60 \%$. Of the area of cultivable land, this calls for the necessity of using this vital resource and using it in the production of various crops and similar studies Nisreen (2009) conducted an analytical study of the price policy of wheat and barley crops and their impact on areas and production from grain crops, wheat and barley in Libya, and the study showed that the production areas of these two crops are subject to fluctuation and decline. From to other for several reasons, foremost of which are the prices of these two crops, which are not commensurate with the production costs, which leads to a decrease in per hectare of them. 


\section{Rainfall}

Rainfall is one of the most important drivers of ecosystem and productivity (Salimon \& Anderson, 2018). Due to the increasing need for water and the clear shortage of its resources, climate change and its evident impacts became one of the debatable issues among the researchers. This is especially important in Libya which suffers from water scarcity; Libya experiences the droughts season which affects water resources.

Interestingly, a review of rainfall effect confirms the findings from the above-mentioned studies. Harraga et al. (1991) aims to identify the development of the area, production, and productivity of a hectare of wheat and barley in Libya during the period (1960-1991), as the study concluded that there is a variation in the quantities available per person annually of wheat and barley, and this may be due to a fluctuation in the quantities of local production Resulting from the fluctuation of rain. Consistent with these results, Al-Selqini et al. (1993) on his study the economics of supplemental irrigation of cereal crops in Libya. The study used to evaluation of the current situation of projects use of supplementary irrigation of grain crops in the western region and to identify the most important problems. The study results confirmed that there is a big gap between the productivity of irrigated and rain-fed cereal crops, due to the variation in rainfall rates in different seasons.

In another study that complements the previous study, conducted by the same researchers in (1993) on the cultivation systems of cereal crops in Libya, where it was evident from the study that the productivity of cereal crops (wheat and barley) decreased and fluctuated greatly from year to year. Al-Hamali (1994) studied the reality of cultivating rain-fed grain crops and the economics of their production in the eastern regions of Libya. The outcomes of this study revealed that most farmers do not invest in this cultivation and do not use advanced technical methods in rain-fed agriculture because of their exposure to risks and the possibility of crop failure, which depends on the levels of rain. In Libyan Desert projects, Shalgam (1995) examined in a study on wheat productivity in desert projects. His analysis found that wheat production varied from one project to another, due to the delay in planting dates, poor soil nutrients and poor rain.

In another study, Zawam (2007) examined the factors affecting the production and consumption of the most important cereal crops in Libya. The study aimed to identify the problem of production and consumption of the most important cereal crops (wheat and barley) and to study the factors determining productivity. The finding of this study found that the most important factors that determine the wheat planting in Libyan are the rainfall variable. Abdel-Razek (2007) also investigated conducted in her study on the determinants of wheat production in Libya. The results of the study found there is that there is a positive relationship between the level of rain and the number of human working hours and wheat production. In some similar, Saad (2009) aimed to compare the cultivation of wheat and barley crops in public agricultural projects and private sector farms in terms of their efficiency in using the water component in the Sabha area. The study revealed that the most important economic inputs affecting wheat production are the amount of rain, the amount of phosphate fertilizer and nitrogen fertilizer, and the amount of compound fertilizer, the amount of seeds, the number of hours of human work, the number of automated work hours and providing the actual needs of water and not relying on rain as the only component of water in the general productive projects. 


\section{Temperature}

Climate change, especially temperature, has an impact on production, and this requires the care of agricultural policymakers, farmers, and seed breeders to ensure sufficiency in global production (Zhao et al., 2017). The study of the direct effect of temperature has not been studied in empirical studies much in Libya, so we will rely on studies in other countries. Asseng et al. (2011) studied the relationship between temperature variability and wheat production by using simulation modelling to show the effect of temperature on wheat production. The study results showed that observed variations in average growing-season temperatures of +$2 \mathrm{C}$ in the main wheat growing regions of Australia can cause reductions in grain production of up to $50 \%$. Most of this can be attributed to increased leaf senescence because of temperatures $>34 \mathrm{C}$. in another study, conducted by Zhao et al. (2017), they investigated the extent to which the wheat crop was affected by changes in temperature. The results of the study showed that there is a negative impact of increasing in temperature one degree Celsius in global, it reduces wheat production.

\section{Data and Methodology Data Collection}

To address the proposed objective of the study, secondary data was used. The available secondary data on wheat production, cultivated area, rainfall, and temperature were collected from different secondary sources. The sources consist of annual reports from Libyan Central Bank, Food General Authority of Grains (Libya), General Information Authority (Libya), Ministry of Planning (Libya), Agricultural Research Centre, Meteorological Department (Libya) and Bureau of Statistics and Census (Libya) as well as the Arab Organization for Agricultural and Food and Agriculture Organization (FAO) over the study period of 1980 to 2014. To examine the effect of cultivated are, rainfall and temperature factor on wheat production, through comprehensive data gathering. It is also used to explain the wheat production in Libya, as well as the trend of wheat per capita.

\section{Model Specification}

In order to identify the production factors that impact wheat production, the study used the ARDL model to estimate the long-run relationship between the variables. Basically, it adopted a generalized version of the Borresch (1928) model. This is an evaluation model that has been used extensively by early studies to measure the value relevance of wheat production, e.g. This model is based upon quantity theory of production.

According to the above-mentioned model, three accounting variables influence the wheat production. However, the present study is consistent with the studies of Al-Maslati (2012), Salimon and Anderson (2018), Chandio et al (2020), Bairagi and Hassan (2002), Dempewolf et al. (2013), Crop Reporting Services (2014), Salem (1989). Goyal and Verma (2015), Manjunath et al. (2002) to Eliw et al (2019) model by incorporating other variables which are expected to be influencing the wheat production. The model of the current study is formulated as follows:

$\mathrm{Y}=\mathrm{a}+\mathrm{b}_{1} \mathrm{x}_{1}+\mathrm{b} 2 \mathrm{x}_{2}+\mathrm{b} 3 \mathrm{x}_{3}+e_{t}$

By converting Model No. (1) to logarithmic form, the model can be written in the following form: -

$\ln Y_{t}=B_{0}+B_{1} \ln X_{1}+B_{2} \ln X_{2 t}+B_{3} \ln X_{3 t}+\varepsilon$ 
Since the variables in logarithmic form, it is expected that the relationship with the dependent variable is to be positive or negative in long- run $B_{1}+, B_{2}+-, B_{3}^{+-}$.

Subsequently, the relationship between the variables is estimated using ARDL model as in Equation (3).

$$
\begin{aligned}
& \Delta \ln W P \\
& =\beta_{0}+\sum_{i=1}^{n} \beta_{1} \Delta \ln w p_{t-1}+\sum_{i=0}^{n} \beta_{2} \Delta \ln C a_{t-1}+\sum_{i=0}^{n} \beta_{3} \Delta \ln R a_{t-1}+\sum_{i=0}^{n} \beta_{4} \Delta \ln T e_{t-1} \\
& +\varepsilon_{t}
\end{aligned}
$$

where:

$W P=$ Wheat production;

$\mathrm{Ca}=$ Cultivated area;

$\mathrm{Ra}=$ Rainfall;

$\mathrm{Te}=$ Temperature;

$\Delta=$ First Difference of Variable;

In = Natural Logarithmic Transformation;

$\beta_{0}=$ Constant; and

$\varepsilon_{t}=$ White Noise error term.

A dynamic error correction model can be obtained from the ARDL model through a simple linear transformation; thus, the error correction version of the ARDL model can be expressed as:

where:

$$
\Delta W P_{\mathrm{t}}=\alpha+\sum_{\substack{\mathrm{i}=1 \\+\eta \mathrm{ECT}_{\mathrm{t}-1}+\text { et }}}^{\mathrm{P}} \beta_{1 \mathrm{i}} \Delta \ln W p_{\mathrm{t}-\mathrm{i}}+\sum_{\mathrm{i}=1}^{\mathrm{P}} \beta_{2 \mathrm{i}} \Delta \ln \mathrm{Ca}_{\mathrm{t}-\mathrm{i}}+\sum_{\mathrm{i}=1}^{\mathrm{P}} \beta_{3 \mathrm{i}} \Delta \ln \operatorname{la}_{\mathrm{t}-\mathrm{i}}+\sum_{\mathrm{i}=1}^{\mathrm{P}} \beta_{4 \mathrm{i}} \Delta \ln \ln _{\mathrm{t}-\mathrm{i}}
$$

$E C T=$ Error Correction Term

$e_{\mathrm{t}} \quad=\quad$ Disturbance Term

The error correction term indicates the speed of adjustment from short-run to long-run equilibrium and it should be statistically significant with a negative sign speed with which the model returns to equilibrium by following an exogenous shock, which may be negatively signed, indicating a move back towards the equilibrium.

\section{Empirical Results}

\section{Unit Root Tests Results}

The Augmented Dickey-Fuller (ADF) and Phillips-Perron (PP) tests are employed to analyse the stationarity of all the variables in our model. Both the augmented Dickey-Fuller (1979) and Phillips-Perron (1988). The results of the unit root test both, the ADF and PP show that in Table 1 and Table 2, the time series variables are stationary at level $1(0)$ series and $1(1)$. Therefore, the mix of integrated orders of the time series variables allows for the estimation of the autoregressive direct lag (ARDL) approach by Pesaran et al. (2001) in this research. In order to select the appropriate model of the long run underlying equation, the Akaike Information Criterion (AIC) for order selection criteria was used. In this research, the optimal 
model is selected based on AIC in which it can be performed in a small sample (Enders, 2004). Following the AIC, the optimal lag for the first model (ACS) is one as shown in Table 3.

Table 1: Results of Unit Root Test for ADF Tests

\begin{tabular}{cccc}
\hline Variables & Level & First Difference & Decision \\
\hline $\mathrm{Wp}$ & -1.798 & -5.946 & $1(1)$ \\
$\mathrm{Ca}$ & -2.231 & -6.141 & $1(1)$ \\
$\mathrm{Ra}$ & -3.262 & -5.856 & $1(0)$ \\
$\mathrm{Te}$ & -0.467 & -8.208 & $1(1)$ \\
\hline \multicolumn{5}{c}{ Critical Values } \\
\hline$\%$ & -3.639 & & \\
$10 \%$ & -2.951 & -3.646 & \\
\hline
\end{tabular}

Note: $\mathrm{Wp}=$ wheat production; $\mathrm{Ca}=$ Culatived area; $\mathrm{Ra}=$ Rainfall; $\mathrm{Te}=$ Temperature.

The null hypothesis is that series is non-stationary or contains a unit root. The rejection of null hypothesis is based on the critical values and numbers in parentheses indicate number of lags $(k)$

* Indicates the rejection of null hypothesis at $5 \%$ level of significance

Table 2: Results of Unit Root Test for PP Tests

\begin{tabular}{cccc}
\hline Variables & Level & First Difference & \\
\cline { 2 - 3 } & Intercept & Intercept \& Trend & Decision \\
\hline Wp & -1.890 & -5.939 & $1(1)$ \\
$\mathrm{Ca}$ & -2.231 & -6.141 & $1(1)$ \\
$\mathrm{Ra}$ & -3.283 & -14.927 & $1(0)$ \\
$\mathrm{Te}$ & -3.521 & -14.978 & $1(0)$ \\
\hline \multicolumn{5}{c}{ Critical Values } \\
\hline $1 \%$ & -3.59 & -3.60 & \\
$5 \%$ & -2.93 & -2.93 & \\
$10 \%$ & -2.60 & -2.60 & \\
\hline
\end{tabular}

Note: $\mathrm{Wp}=$ wheat production; $\mathrm{Ca}=$ Culatived area; $\mathrm{Ra}=$ Rainfall; $\mathrm{Te}=$ Temperature. The null hypothesis is that series is non-stationary or contains a unit root. The rejection of null hypothesis is based on the critical values and numbers in parentheses indicate number of lags $(k)$

* Indicates the rejection of null hypothesis at $5 \%$ level of significance 
Table 3: VAR Lag Order Selection Criteria

\begin{tabular}{|c|c|c|c|c|c|c|}
\hline Lag & $\log L$ & LR & FPE & AIC & SC & $\mathrm{HQ}$ \\
\hline & 80.8398 & & & - & - & - \\
\hline \multirow[t]{3}{*}{0} & 7 & NA & \multicolumn{4}{|c|}{$8.26 \mathrm{e}-084.9574114 .7723804 .897095$} \\
\hline & & & & - & - & - \\
\hline & 115.129 & 57.5183 & $2.57 e-$ & 6.137395 & 1224 & 835818 \\
\hline \multirow[t]{2}{*}{1} & 6 & $1^{*}$ & $08 *$ & $*$ & $*$ & $*$ \\
\hline & 127.913 & 18.1447 & & - & - & - \\
\hline \multirow[t]{2}{*}{2} & 4 & 3 & \multicolumn{4}{|c|}{ 3.35e-08 5.9298984.2646225.387059 } \\
\hline & 139.806 & 13.8117 & & - & - & - \\
\hline \multirow[t]{2}{*}{3} & 9 & 8 & \multicolumn{4}{|c|}{ 5.08e-08 5.6649613.2595634.880861 } \\
\hline & 152.793 & 11.7296 & & - & - & - \\
\hline 4 & 3 & 4 & $8.50 \mathrm{e}-08$ & 5.470534 & 325014 & 445173 \\
\hline
\end{tabular}

\section{Bound Test Approach}

To investigate the presence of long-run relationships among the variables, the bounds testing procedure (Pesaran et al., 2001) procedure is utilized. The results of Table 4 indicate the calculated F-statistics fall between the lower bound and the upper bound at the 5 percent level. This means that our F-statistic results are inconclusive. Following several studies rely on the error correction model (ECM) results for the better indication for cointegration, as compared to the F-test under the bounds testing procedure due the ECM is a relatively more efficient way to establish cointegration (Kremers et al., 1992). Alternatively, Kremers et al. (1992) and Banerjee et al. (1998) show that in an ECM, a significantly lagged error-correction term is a relatively more efficient way of establishing cointegration. Consequently, the error correction term can be used when the F-test is inconclusive.

Table 4: Cointegration Results of Model

Model Lag Order $\quad$ F-statistics

\begin{tabular}{lll}
\hline WP & 1 & 3.93
\end{tabular}

Critical Value Bounds of the F-statistic: Unrestricted Intercept and No Trend

Significant level

Critical Values

\begin{tabular}{lll}
\cline { 2 - 3 } & $\mathrm{I}(0)$ & $\mathrm{I}(1)$ \\
\hline $90 \%$ & 2.72 & 3.77 \\
$95 \%$ & 3.23 & 4.35 \\
$99 \%$ & 4.29 & 5.61 \\
\hline
\end{tabular}

Note: Critical value bounds of the F-statistic are obtained from Pesaran et al. (2001) 


\section{ARDL Approach}

The generated ARDL long-run estimate is presented in Table 5. The ARDL long-run estimates for wheat production model show that cultivated area ( $\mathrm{Ca}$ ) and rainfall ( $\mathrm{Ra}$ ) are positively related to wheat production while temperature (Te) has a negative association with wheat production. As illustrated in Table 5, the coefficient of cultivated area (0.63) is positive and statistically significant with expected signs at $1 \%$ significance level. Thus, it implies that $1 \%$ rises in the cultivated areas will increase $0.63 \%$ in wheat production in the long-run. Interestingly, the coefficient of the rainfall (RA) variable is showing a positive sign but nonsignificant relationship with the wheat production. Meanwhile, the temperature (Te) has nonsignificant and adverse effect on wheat production by $0.57 \%$.

Based on Table 5 indicate that the short-run dynamic coefficients are not identical to the signal of long-run estimates. With respect to the first explanatory variables, the temperature variable found to be significant in effect at $10 \%$ probability. Regarding to Cultivated area was found to be significant and negative relationship with the wheat production. Furthermore, rainfall was found non-significant at $10 \%$ probability level with an estimated coefficient of 0.13. The ECM coefficient shows the expected negative sign of ECM and highly significant in the model and how quickly variables converge to equilibrium and it should have a statistically significant with a negative sign. The estimated error correction coefficient of $-1.27(0.017)$ is highly significant, has the correct sign, and implies a fairly high speed of adjustment to equilibrium after a shock. Approximately $1.27 \%$ of disequilibria from the previous year's shock converge back to the long-run equilibrium in the current year.

Table 5: ARDL Depended variable in $\operatorname{Ln}$ WP: $\operatorname{ARDL}(1,1,0,1)$

\begin{tabular}{lccc}
\hline Variables & Coefficient & $\begin{array}{l}\text { t-ratio } \\
\text { F-statistic }\end{array}$ & p-value \\
\hline Long-Run Estimation & & & \\
Ln Ca & 0.0639 & $\{6.487\}$ & {$[0.000]$} \\
Ln Ra & 0.0877 & $\{1.487\}$ & {$[0.148]$} \\
Ln Te & -0.573 & $\{-0.999\}$ & {$[0.326]$} \\
C & 0.328 & $\{0.163\}$ & {$[0.871]$} \\
Short-Run Estimation & & & \\
$\Delta$ Ln Ca & -0.648 & $\{-2.406\}$ & {$[0.023]$} \\
$\Delta$ Ln Ra & -0.057 & $\{-1.588\}$ & {$[0.123]$} \\
$\Delta$ Ln Te & 1.528 & $\{1.841\}$ & {$[0.076]$} \\
ECT (-1) & -1.273 & $\{0.504\}$ & {$[0.017]$} \\
Diagnostic Tests & & & \\
Serial Correlation & & $\{0.303\}$ & {$[0.586]$} \\
Normality & & $\{1.668\}$ & {$[0.434]$} \\
Heteroskedasticity & & $\{0.748\}$ & {$[0.722]$} \\
\hline
\end{tabular}

Note: The figures in $\{\ldots\}$ and [...] refer to the t-statistics and probabilities, respectively.

* Indicates the rejection of null hypothesis at $1 \%$ level of significance

** Indicates the rejection of null hypothesis at $5 \%$ level of significance

$* * *$ Indicates the rejection of null hypothesis at $10 \%$ level of significance 
Finally, in order to check the diagnostic test, the model pass all diagnostic tests as shown in Table 5 shows that there is no evidence of serial correlation and the models pass the normality and the test proved that the error is normally distributed. Besides that, the stability is checked through the cumulative sum of the recursive residuals (CUSUM). Figure 1 illustrates the plots for CUSUM within the critical boundaries, revealing that the estimated parameters are stable over the period of study at the $5 \%$ significance level.

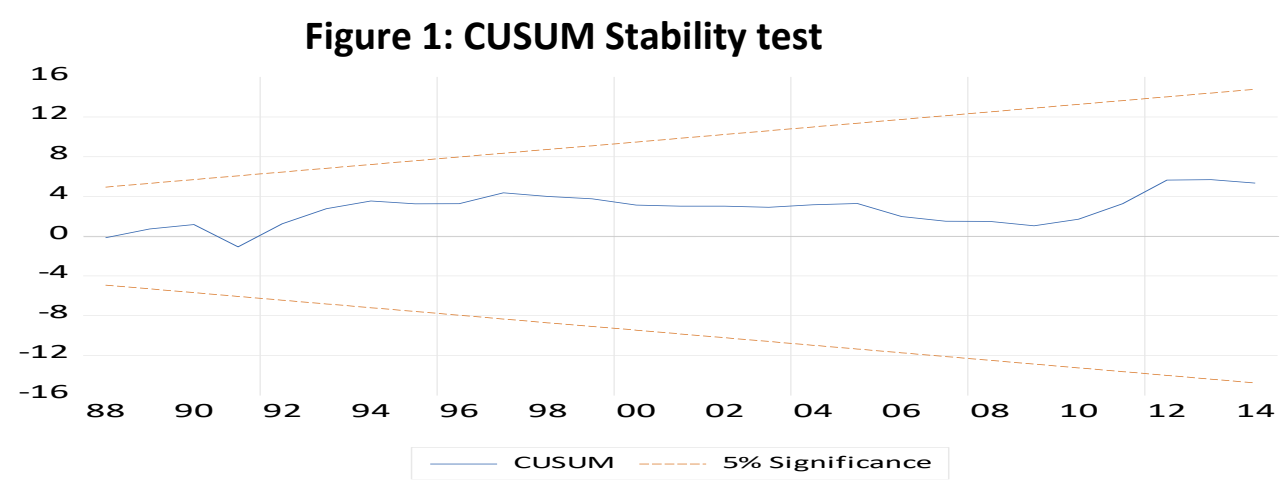

\section{Conclusion}

This research is conducted to investigate the determinants of explanatory variables on wheat production in Libya. This research utilizes secondary data over the period of 1980 to 2014 . The bound testing procedure, the ARDL approach is employed to examine the relationship between the variables under investigation. To test the stationary of the time series variables, both ADF and PP unit root tests are used to test the stationarity at the level and first difference.

The results of the cointegration analysis indicate that there is a long-run cointegration relationship among the variables. The variables, wheat cultivated, and rainfall are found to positively affect the wheat production. Among these variables, only the wheat cultivated area is found to be statistically significant in the Model, while temperature has a negative influence on the dependent variable.

\section{Acknowledgement}

This work is supported by Universiti Malaysia Sarawak [Grant numbers: 2018 F01/SpTDG/1783/2018].

\section{References}

Aty, K. (2018). Analytical study of some factors affecting wheat production in Libya during the period 1990-2015. Sirte University Scientific Journal, 2(1), 247-259.

Abdel-Razek, S. O. (2007). Economic analysis of the determinants of wheat production in Libya. (Unpublished master's thesis). Department of Agricultural Economics, Faculty of Agriculture, Omar Al-Mukhtar University, Al-Bayda, Libya.

Al-Bashir, K., and Mahmoud, Y. A. (2008). Current use and optimization of agricultural land resources in the production of the most important agricultural crops in Libya. Mansoura Journal of Agricultural Science, 33, 218-235.

Al-Dabah. (1991). An Economics study of rain-fed wheat supply in Libya. (Unpublished master's thesis). Al-Fatah University, Tripoli, Libya. 
Al-Hamali, S. M. (1994). Study of the reality of rain fed cereal cultivation and the economics of production in the eastern regions. Agricultural Research Center, Department of Agricultural Economics, Tripoli, Libya.

Al-Maslati, N. (2012). Analytical study of the efficiency of grain production in the Green Mountain region of the Libyan Jamahiriya. (Unpublished doctoral dissertation). Saba Pasha University, Alexandria, Egypt.

Al-Selqini, A. S., Saleh, A., Sasi, A. (1993). Economics of Supplementary Irrigation of Cereal Crops and Evaluation of Permanent Status in the Western Region. Agricultural Research Center, Department of Agricultural Economics, Dates, Tripoli, Libya.

Arab Organization for Agricultural Development (AOAD). (2016). Agricultural Statistics Yearbook. Khartoum, Sudan.

Asseng, S., Foster, I. A. N., and Turner, N. C. (2011). The impact of temperature variability on wheat yields. Global Change Biology, 17(2), 997-1012.

Bairagi, G. D., and Hassan, Z. U. (2002). Wheat crop production estimation using satellite data. Journal of the Indian Society of Remote Sensing, 30(4), 213.

Banerjee, A., Dolado, J. J., and Mestre, R. (1998). Error-correction mechanism tests for cointegration in a single equation framework. Journal of Time Series Analysis, 19, 267283.

Bashir, A. B. (1996). An Economic study of grain production (wheat and barley) in Libya during (1970-1996). (Unpublished master's thesis). Academy of high studies and economic Research. Tripoli, Libya.

Bijaya, K. M. (2010). Agricultural Financing and Rural Development. Regal Publications. New Delhi, India.

Boresch, K. U. (1928). Ertragsgesetze bei Pflanzen. Ergebnisser der Biologie, 4, 130-204.

Chandio, A. A., Jiang, Y., Rehman, A., and Rauf, A. (2020). Short and long-run impacts of climate change on agriculture: an empirical evidence from China. International Journal of Climate Change Strategies and Management.

Crop Reporting Services (2014). Second estimate of wheat crop in the Punjab for the year 2013-14. Govt. of Punjab, Lahore.

Darwish, S., Abdo, H., \& AlShuwaiee, W. M. (2018). Opportunities, challenges and risks of transition into renewable energy: the case of the Arab Gulf Cooperation Council. International Energy Journal, 18(4).

Dempewolf, J., Adusei, B., Becker-Reshef, I., Barker, B., Potapov, P., Hansen, M., and Justice, C. (2013). Wheat production forecasting for Pakistan from satellite data. In 2013 IEEE International Geoscience and Remote Sensing Symposium-IGARSS (pp. 3239-3242). IEEE.

Dickey, D. A., and Fuller, W. A. (1979). Distribution of the estimators for autoregressive time series with a unit root. Journal of the American statistical association, 74(366a), 427431.

Edgerton, M. D. (2009). Increasing crop productivity to meet global needs for feed, food, and fuel. Plant Physiology, 149(1), 7-13.

Eliw, M., Mottawea, A., and El-Shafei, A. (2019). Estimating Supply Response of Some Strategic Crops in Egypt Using ARDL Model. South Asian Journal of Social Studies and Economics, 1-22.

Enders, W. (2004). Applied Econometrics Time Series $2^{\text {nd }}$. New York: John Wiley and son, Inc. Food and Agriculture Organization of the United Nations. (2020). FAO. Retrieved October 2, 2020, from http://faostat.fao.org 
Gade, A. (2006). Estimate the function of wheat supply response in Libya. International Journal of Nasser, 1, 159-175.

Goyal, M., and Verma, U. (2015). Development of weather-spectral models for pre-harvest wheat yield prediction on agro-climatic zone basis in Haryana (India). International Journal of Agricultural Statistics Science, 11(1), 73-79.

Harraga, S., Saleh A., Rabia I., and Ahlam, S. (1991). Wheat and barley facts and figures over the years (1968-1991). Agricultural Research Center, Department of Agricultural Economics. Tripoli, Libya.

Khayriyah, A. H. (2005). Economic study of food security in Libya. (Unpublished master's thesis). Department of Agricultural Economics Alexandria University, Alexandria, Egypt.

Kremers, J. J. M., Ericsson, N. R., and Dolado, J. J. (1992). The power of cointegration tests. Oxford Bulletin of Economics and Statistics, 54, 325-348.

Praburaj, L. (2018). Role of Agriculture in the Economic Development of a Country. Shanlax International Journal of Commerce, 6(3), 1-5.

Manjunath, K. R., Potdar, M. B., and Purohit, N. L. (2002). Large area operational wheat yield model development and validation based on spectral and meteorological data. International Journal of Remote Sensing, 23(15), 3023-3038.

Ministry of Information and Culture. (1994). Political, Economic and Social Transitions (19691994). Tripoli, Libya.

Morris, C. F., and Rose, S. P. (1996). Wheat. In Cereal Grain Quality (pp. 3-54). Springer, Dordrecht.

Nisreen, R. M. (2009). An analytical study of the price policy of wheat and barley crops and their effect on areas and production of crops in Libya. (Unpublished master's thesis). Department of Agricultural Economics, Faculty of Agriculture, Omar Al-Mukhtar University, Al-Bayda, Libya.

Nurgaziev, M. (2010). The Role of Agricultural credit on farm development in Kyrgyzstan: A case study of peasants in Chui, Osh and Jalal-Abad Regions. Margraf Publishing, 122.

Pesaran, M. H., Shin, Y., and Smith, R. J. (2001). Bounds testing approaches to the analysis of level relationships. Journal of Applied Econometrics, 16, 289-326.

Phillips, P. C., and Perron, P. (1988). Testing for a unit root in time series regression. Biometrika, 75(2), 335-346.

Saad, A. M. (2009). Economic evaluation of the cultivation of wheat and barley crops on the irrigated system of some governmental and private agricultural projects. (Unpublished master's thesis). Department of Agricultural Economics, Faculty of Agriculture, Omar Al-Mukhtar University, Al-Bayda, Libya.

Salem, M. A. (1989). Farmers' attitudes towards risk in dry land wheat production areas in Jordan. Dirasat.

Salimon, C., and Anderson, L. (2018). How strong is the relationship between rainfall variability and Caatinga productivity? A case study under a changing climate. Anais da Academia Brasileira de Ciências, 90(2), 2121-2127.

Shalgam, M. M. (1995). The productivity of wheat and barley in desert area and food security symposium. The National Authority for Scientific Research, Tripoli, Libya.

Shewry, P. R., and Hey, S. J. (2015). The contribution of wheat to human diet and health. Food and Energy Security, 4(3), 178-202. 
Shiferaw, B., Smale, M., Braun, H. (2013). Crops that feed the world 10. Past successes and future challenges to the role played by wheat in global food security. Food Security 5, 291-317.

Zawam, A. A. F. (2007). An economic study of the factors affecting the production and consumption of the most important cereal crop in Libya. (Unpublished doctoral dissertation). Department of Agricultural Economics. Faculty of Agriculture (Saba Basha), Alexandria University, Alexandria, Egypt. 